\title{
SZYK WYRAŻEŃ JAKO CECHA DYSTYNKTYWNA W POLU KOMENTARZY METATEKSTOWYCH: [ADV] MÓWIĄC, _ VS MÓWIĄC [ADV], -
}

\section{WPROWADZENIE}

$\mathrm{W}$ ostatnich latach $\mathrm{w}$ językoznawstwie, nie tylko polskim, widoczny jest wyraźny wzrost zainteresowania tzw. słownictwem gramatycznym, w tym wyrażeniami funkcyjnymi i metatekstowymi. Uwaga badaczy koncentruje się, w zależności od tradycji lingwistycznej, przyjmowanej metodologii i punktu widzenia, badź to na opisie semantyczno-syntaktycznym poszczególnych klas, podklas oraz elementów języka i ich funkcji w aspekcie synchronicznym, badź to na zmianach językowych i ich schematach, w wyniku których powsta(wa)ła ta grupa wyrażeń. Podstawowe dla opisu tego pola leksykalno-funkcjonalnego założenia - takie jak np. status tych wyrażeń w języku (element systemu vs jego realizacja; por. semantyka vs pragmatyka), ich zawartość pojęciowa (wyrażenie o znaczeniu konkretnym (leksykalnym) vs abstrakcyjnym (gramatycznym)) - przyjmowane sa każdorazowo w punkcie wyjścia analizy i zależą od wybranej koncepcji metodologicznej wpisującej się w ogólną teorię języka (tym samym funkcjonuja na prawach twierdzeń apriorycznych). Konsekwencją takiego stanu rzeczy jest ogromne zróżnicowanie koncepcyjno-terminologiczne w odniesieniu do badań tej podklasy wyrażeń, por. różne teorie gramatykalizacji, badań relacji tekstowych, teorii argumentacji, leksykalnych analiz składniowo-semantycznych czy dyskursu.

Prezentowane tu analizy reprezentuja nurt badań nad wyrażeniami funkcyjnymi i metatekstowymi prowadzonych w ramach koncepcji metodologicznej ukształtowanej przez Andrzeja Bogusławskiego i Annę Wierzbicka, rozwijanej przez Macieja Grochowskiego i Jadwigę Wajszczuk, ukierunkowany na opis poprawnie wyodrębnionych bytów językowych (bilateralnych jednostek języka) i ich funkcji w systemie oraz ich realizacji w tekstach. Na Saussure'owskiej opozycji langue vs parole opiera się ścisłe rozróżnienie semantyki (narzędzi językowych) i pragmatyki (działań za pomoca tych narzędzi), zob. Bogusławski 2008. W ramach tej koncepcji przyjmuje się, że elementy leksykalne moga reprezentować poziom 
przedmiotowy języka (analizowany w perspektywie składniowo-semantycznej) bądź poziom metatekstu (wymagający opisu funkcjonalno-semantycznego). Uznaje się, że o odmienności funkcji wyrażeń (ściślej: o odrębności jednostek języka) może decydować nawet najdrobniejsze zróżnicowanie strony materialnej lub znaczeniowej wyrażeń, zob. Bogusławski 1989. Celem artykułu jest zwrócenie uwagi na istotność w opisie języka tego ostatniego aspektu poprzez scharakteryzowanie szyku jako właściwości różnicującej byty językowe w klasie komentarzy metatekstowych.

\section{QUASI-IMIESEOWOWE KOMENTARZE METATEKSTOWE}

Podstawowa i najliczniejsza grupę komentarzy metatekstowych stanowia konstrukcje $z$ quasi-imiesłowowym elementem mówią, rzecz biorac, rzecz ujmując, ujmujac, biorac, np. delikatnie mówiąc, _; najogólniej mówiąc, _; ogólnie rzecz biorac, _; łagodnie rzecz ujmujac, _; najogólniej biorac, _; historycznie ujmujac, _; mówiac wprost, _; ujmujac rzecz najdelikatniej, _ służące - jak to się na ogół formułuje - do wyrażania stosunku mówiącego względem treści lub formy wypowiedzi, por.:

(1) Młynarka nie była, delikatnie mówiac, $w$ najlepszej formie.

(2) Najogólniej mówiąc, „badź grzeczny” w ustach rodziców często znaczy: daj mi święty spokój.

(3) Działacze byli różnego pokroju, jedni bardziej chwytali pewne sprawy, inni mniej, ale ogólnie rzecz biorac, byli bardzo dobrze zorganizowani.

(4) Doradcy - najogólniej rzecz ujmujac, udzielaja bezrobotnemu pomocy $w$ wyborze zawodu, zgodnie z jego kwalifikacjami i wyobrażeniami o dobrej pracy.

(5) Otóż, mówiąc najprościej, doktor Twardowski zamierza przeprowadzić i ocenić „próbe złota”.

(6) Kiedy mówi się o ekologii, ludzie maja na myśli zazwyczaj „ochrone przyrody", tymczasem ekologia - biorac rzecz dosłownie - jest nauka o naszym domu, środowisku, w którym przyszło nam żyć.

Analizowane tu wyrażenia pełniące funkcję aktualnych komentarzy odnadawczych różnia się od regularnych użyć imiesłowów czynnych czasownika tym, że nie wskazują na współzachodzenie oznaczanych zdarzeń (w tym czynności mownych) przy tym samym podmiocie, zob. np. Wróbel 1975, ale stanowia charakterystyki bieżacych wypowiedzi [na temat utraty kategorialnych cech imiesłowu zob. Weiss 2005], por. przykłady użyć imiesłowów:

(7) Mówiac to, podszedł do mapy. 
(8) Bardzo sie ucieszyłem, kiedy to powiedziała, ale nic nie dodałem i tanczyliśmy, nic nie mówiąc.

(9) - Nie lubi pan tego życia, prawda? - oskarżała, nie mówiąc wprost, o co jej chodzi.

(10) Ujmując rzecz ogólniej, uświadomił nam, że jest to problem ogólnoludzki.

Ewentualna dwuznaczność interpretacji, por. przykład (10), który może stanowić realizację bądź konstrukcji imiesłowowej, bądź aktualnego komentarza odnadawczego, dotyczy wyłącznie zdań bezkontekstowych - w konkretnych użyciach realizacja prozodyczna wspomagana przez kontekst w sposób jednoznaczny przesądza, jaką rolę względem tzw. zdania głównego odgrywa forma imiesłowu.

Ze względu na odmienność funkcji konstrukcji z mówiac, rzecz biorac, rzecz ujmujac, biorac, ujmując w kontekstach typu (1)-(6) w stosunku do roli, jaka pełnia w zdaniu imiesłowy jako formy fleksyjne czasownika, wyrażenia takie nazywane są imiesłowami parentetycznymi [Moroz 2007; 2010] czy quasi-imiesłowami [Stępień 2014]. Na podstawie relacji względem pozostałej części zdania, tj. samej realizowanej właśnie wypowiedzi, jako jej d o d a tk ow e charakterystyki, quasi-imiesłowy (dalej: Q-I) uznawane sa za komentarze metatekstowe [Wajszczuk 1997; Bogusławski, Danielewiczowa 2005; Kisiel, Żabowska 2011]. Sa one formalnie włączane do zdania jako struktury tzw. wtracone (inherentnie parentetyczne) [por. Moroz 2010; Stępień 2014]. Z kolei wymienność wyrażeń reprezentujacych towarzyszacy im element przysłówkowy, por. delikatnie, łagodnie, ogólnie, ściśle, konkretnie, precyzyjniej, najogólniej itd., jest argumentem za kompozycjonalnością ciagów złożonych $z$ elementu adwerbialnego i Q-I. Tym samym przyjmuje się, że właściwe byty językowe konstytuowane sa przez segment o kształcie (ale nie: funkcji) imiesłowu otwierajacy pozycję dla uzupełnienia przysłówkowego, por. [jakoś] mówiac, _; [jakoś] rzecz biorac, _. itd. ${ }^{1}$

Niektóre $z$ analogicznych połączeń notowane sa jako osobne jednostki języka, ${ }^{2}$ np. krótko mówiac, nawiasem mówiac; $z$ leksykalizacja związana jest zmiana funkcji wyrażenia w strukturze komunikacyjnej wypowie-

1 Takie rozstrzygnięcie zastosowano także w ISJP, por. „Słowa mówiąc w połączeniu $z$ określeniem przysłówkowym używamy, aby uczynić komentarz na temat naszej wypowiedzi, np. uściślić ja, osłabić lub zdystansować się do niej (PART $[\mathrm{OK}]=$ powiedziawszy)".

2 Por. także inne jednostki języka $z$ segmentem imiesłowowym, np. niedaleko szukając, chcac nie chcac, lekko liczac, niewiele myślac, nie przymierzajac. Takie połączenia - ze względu na brak możliwości substytucji któregokolwiek $z$ segmentów, co jest równoznaczne $z$ niezachodzeniem proporcji formalno-funkcjonalnej w układach $z$ innymi elementami - muszą być rejestrowane jako osobne byty leksykalne. 
dzenia, por. odnotowane w SGPP jako partykuły krótko mówiąc, między nami mówiac, nawiasem mówiac, ${ }^{3} \mathrm{np}$.:

(11) I oczywiście: rozwydrzony tłum przewodników, oślarzy i agentów turystycznych. Pucybuci i fotografowie. Osły i wielbłady. Zgiełk i tłok jak na świątecznym jarmarku w Łowiczu. Krótko mówiąc, osławiona Giza rozczarowała nas.

(12) Choć naciskany, do wyjaśnień przystapił Horn dopiero po obiedzie. Który, nawiasem mówiąc, zjadł ze smakiem.

Przyjmuje się także, że analizowane tu konstrukcje (bezpośrednio lub w wyniku zmian formy i/lub funkcji wyrażenia zleksykalizowanego, por. np. nawiasem mówiąc, które może być skracane do nawiasem (SGPP)), mogą stać się bazą dla samodzielnych użyć elementów przysłówkowych, np. krótko:_; _, ściślej, _; najogólniej, _; por.:

(13) $Z$ natury nie jestem łatwowierny. A do tego mówi Pismo: nie dowierzajcie każdemu duchowi. Gdyż wielu fałszywych proroków pojawiło sie na świecie. Krótko: kłamca na kłamcy i kłamca pogania.

(14) Mówi, że podczas zwykłej, zalecanej kuracji wstrzasowej doszło do nieodwracalnej losowej tragedii. Ściślej: do katastrofy, do śmiertelnej niejako kraksy.

(15) Chodzi tu, najogólniej, o przyjęta hierarchię wartości, w myśl której honor oficera (lub żolnierza) jest wartościa nadrzędna (...).

(16) - Porzadni i śmiali z was ludzie, panie Szarleju i ty, paniczu von Hagenau. Nawiasem, czyście jaki potomek tego sławnego poety?

Jak pokazuja przywołane najważniejsze wnioski $z$ dotychczasowych analiz interesujących nas tu wyrażeń, tezy na temat roli, jaka pełnia one w zdaniu oraz zmian ich funkcji, charakteryzuja się dość dużym stopniem uogólnienia. Adekwatny ich opis wymaga ścisłego rozgraniczenia pełnionych przez nie funkcji, których odbiciem są właściwości linearno-prozodyczne wraz ze zróżnicowaniem formalnym i leksykalnym wchodzących w ich skład przysłówków. Dopiero kolejnym krokiem analizy może być wskazanie warunków leksykalizacji niektórych konstrukcji oraz usamodzielniania się elementu adwerbialnego $\mathrm{w}$ funkcji metakomentującej.

3 WSJP notuje w postaci osobnych haseł $z$ segmentem mówiąc komentarze metatekstowe inaczej mówią, prawdę mówiac, szczerze mówiąc i partykuły krótko mówią, nawiasem mówiąc, na marginesie mówiac, mówiąc między nami [dostęp: 22.02.2020]. We wcześniejszych słownikach wyrażenia z Q-I były kwalifikowane jako operatory metatekstowe [SWJP] i partykuły [ISJP]. 


\section{DWA TYPY KONSTRUKCJI: [ADV] MÓWIĄC, _ VS MÓWIĄC [ADV], -}

W literaturze przedmiotu najwięcej uwagi poświęcono konstrukcjom z [jakoś] mówiąc, _ (dalej: [Adv] mówiąc,_): opisana została funkcja i właściwości prozodyczne tej jednostki [Stępień 2014], typy i cechy formalne przysłówków, które wchodza na otwierana pozycję [Kubicka 2017], pochodzenie takich konstrukcji [Birzer 2017], a także sformułowano hipotezy na temat warunków usamodzielniania się przysłówków (por. tezę Krystyny Kleszczowej [2015] o zerowaniu autoreferującej parentezy; Emilia Kubicka [2017] przywołuje hipotezę o wpływie częstości wystapień danego przysłówka na możliwość pominięcia Q-I). Obraz, jaki się wyłania $z$ tych opisów, choć odzwierciedla istotne właściwości takich konstrukcji, nie oddaje, w moim przekonaniu, istoty rzeczy. Otóż, by wyjaśnić funkcję interesujących nas tu metakomentarzy, wydzielić trzeba, i to już na wstępnym etapie analizy, dwa osobne typy konstrukcji, zróżnicowane ze względu na funkcję ( $\mathrm{z}$ czym współgra odmienny szyk elementów składowych i ich właściwości prozodyczne), mianowicie - ujmując rzecz wstępnie - [Adv] mówiąc, _oraz mówiąc [Adv], _. Układy te, wbrew temu, co się przyjmuje w literaturze, nie moga być uznane za realizacje wariantywne: $z$ różnica prozodyczno-linearna związana jest bowiem istotna różnica semantyczno-funkcjonalna. Odznaczaja się one także zróżnicowaniem zarówno leksykalnym, jak i formalnym elementów przysłówkowych, a w konsekwencji także możliwością odniesienia do nich negacji oraz odmiennymi warunkami samodzielnego użycia przysłówków.

\subsection{Przysłówki w quasi-imiesłowowych komentarzach metatekstowych}

Na klasę wyrażeń zdolnych do wypełnienia pozycji [Adv] nałożony jest warunek możliwości współwystępowania, najogólniej rzecz ujmując, $\mathrm{z}$ czasownikami działań mownych, np. powiedzieć // wyrazić, ściśle, delikatnie, właściwie, i czynności mownych, ${ }^{4} \mathrm{np}$. ujmować // powiedzieć ogólnie, schematycznie, wprost, złośliwie, otwarcie. Ich zestaw jest dodatkowo ograniczony do tych przysłówków, które moga posłużyć do realizowania funkcji metakomentarza - warunku tego nie spełniaja na przykład przysłówki kwalifikujące orzekanie typu słusznie, prawdziwie, por. słusznie powiedział, że _ vs *słusznie mówią, _; prawdziwie orzekt, $\dot{z} e_{\text {_ vs }}$ * prawdziwie mówiąc, _, czy przysłówki charakteryzujące czynno-

${ }^{4} \mathrm{~W}$ przyjętym tu rozumieniu działania i czynności mowne polegaja na dokonywaniu operacji na treści komunikatu, czynności werbalne zaś - na jego formie. Z kolei działania mowne służa jak najlepszemu sformułowaniu komunikatu ze względu na to, co się chce powiedzieć, a czynności mowne - jak najbardziej adekwatnej jego realizacji, por. mówię TO vs mówię TAK. 
ści werbalne, np. głośno, wyraźnie, np. powiedział głośno // wyraźnie, że _ vs * mówiąc głośno, _; *wyraźnie mówiąc, _. Niezależnie od tego aktualne komentarze odnadawcze obłożone sa zakazem przyłączania tych przysłówków, które wskazuja na negatywna kwalifikację prawdziwościowa, por. "mylnie // *błędnie // *kłamliwie rzecz ujmujac, _, zob. 3.3.

Pierwszym argumentem za odrębnością dwóch typów konstrukcji $z$ odmiennym układem linearnym, por. [Adv] mówiąc, _ i mówiąc [Adv], _, jest zróżnicowanie leksykalne przysłówków, które moga takie konstrukcje współtworzyć. Rzecz dotyczy mutatis mutandis układów z rzecz ujmujac, rzecz biorac, które nie będą tu szczegółowo opisywane, charakteryzuja się one bowiem własnym zestawem przysłówków. Co więcej, metakomentarze z biorac i ujmując, ze względu na wyraźną eliptyczność, cechuja się także ograniczeniami co do szyku postpozycyjnego elementu adwerbialnego, por. narzucajace sie pytanie co biorac?, co ujmujac? (np. Historycznie ujmujac, zasadniczy impuls do zmiany struktury własnościowej polskiego systemu bankowego stworzyła ustawa - prawo bankowe z 1989 r.); w odróżnieniu od nich mówiac swoje co? realizuje w postaci komentowanej frazy. Mianowicie obok przysłówków, które mogą wystąpić zarówno w antepozycji, jak i postpozycji względem Q-I, wyraźnie wyodrębniają się grupy przysłówków, które pojawiają się tylko w jednym typie konstrukcji, ${ }^{5}$ por.:

Tabela 1. Występowanie przysłówków w konstrukcjach quasi-imiesłowowych o odmiennym szyku

\begin{tabular}{|c|c|c|}
\hline & [Adv] Q-I, _- & Q-I [Adv], _- \\
\hline \multirow[t]{3}{*}{ mówiąc } & $\begin{array}{l}\text { ogólnie, inaczej, szczerze, } \\
\text { delikatnie, właściwie mówiąc, }\end{array}$ & $\begin{array}{l}\text { mówiac ogólnie, inaczej, szczerze, } \\
\text { delikatnie, właściwie, }\end{array}$ \\
\hline & $\begin{array}{l}\text { *wprost, *skrótowo, *w skrócie, } \\
\text { *serio, *obrazowo, * najogledniej, } \\
\text { *w uproszczeniu, * przewrotnie, } \\
\text { *językiem biologii mówiac, _- }\end{array}$ & $\begin{array}{l}\text { mówiac wprost, skrótowo, } \\
\text { w skrócie, serio, obrazowo, } \\
\text { najogledniej, w uproszczeniu, } \\
\text { przewrotnie, językiem biologii, }\end{array}$ \\
\hline & $\begin{array}{l}\text { ściśle, generalnie, praktycznie } \\
\text { mówiąc, _- }\end{array}$ & $\begin{array}{l}\text { mówiac *ściśle, *generalnie, } \\
\text { *praktycznie, _ }\end{array}$ \\
\hline
\end{tabular}

${ }^{5}$ Odmienna łączliwość z przysłówkami poszczególnych Q-I wskazuje na ich niesynonimiczność, por. np. brutalnie rzecz ujmując // mówiąc // *rzecz biorac. 


\begin{tabular}{|c|c|c|}
\hline & [Adv] Q-I, _- & Q-I [Adv], _- \\
\hline \multirow{3}{*}{$\begin{array}{l}\text { rzecz } \\
\text { biorac / } \\
\text { biorac } \\
\text { rzecz }\end{array}$} & ogólnie, historycznie rzecz biorąc, _ & biorąc rzecz ogólnie, historycznie, _ \\
\hline & $\begin{array}{l}\text { * procentowo, * na chłopski rozum, } \\
\text { *en bloc, *en masse, * na chłodno, } \\
\text { *serio rzecz biorac, .- }\end{array}$ & $\begin{array}{l}\text { biorac rzecz procentowo, na } \\
\text { chłopski rozum, en bloc, en masse, } \\
\text { na chłodno, serio, }\end{array}$ \\
\hline & $\begin{array}{l}\text { zasadniczo, praktycznie, } \\
\text { teoretycznie, z grubsza rzecz } \\
\text { biorac,_6 }\end{array}$ & $\begin{array}{l}\text { biorac rzecz *zasadniczo, } \\
\text { *praktycznie, *teoretycznie, } \\
{ }^{*} \text { g grubsza. }\end{array}$ \\
\hline \multirow{3}{*}{$\begin{array}{l}\text { rzecz } \\
\text { ujmujacc/ } \\
\text { ujmujacc } \\
\text { rzecz }\end{array}$} & $\begin{array}{l}\text { delikatnie, ściślej, teoretycznie } \\
\text { rzecz ujmując, }{ }_{-}\end{array}$ & $\begin{array}{l}\text { ujmujac rzecz delikatnie, ściślej, } \\
\text { teoretycznie, _ }\end{array}$ \\
\hline & $\begin{array}{l}\text { *schematycznie, * kiczowato, } \\
\text { *w przenosni, *abstrakcyjnie, } \\
\text { *w trzech zdaniach, *szerzej rzecz } \\
\text { ujmujac, }\end{array}$ & $\begin{array}{l}\text { ujmujac rzecz schematycznie, } \\
\text { kiczowato, w przenośni, } \\
\text { abstrakcyjnie, w trzech zdaniach, } \\
\text { najgrubiej, szerzej, _- }\end{array}$ \\
\hline & generalnie rzecz ujmujac, _ & ujmując rzecz *generalnie, _ \\
\hline
\end{tabular}

Źródło: opracowanie własne.

Zróżnicowaniu leksykalnemu wyrażeń we wskazanych dwóch układach towarzyszy odmienność formy elementu adwerbialnego. Dokładniej mówiąc, tylko układy postpozycyjne dopuszczaja konstrukcje adwerbialne $z$ wyrażeniami rzeczownikowymi typu od strony [jakiejś // czegoś] (np. biorac rzecz od strony historycznej), w aspektach [jakichś] (np. ujmujac rzecz $w$ aspektach socjologicznych), $z$ [jakiegoś] punktu widzenia (np. ujmujac rzecz z naukowego punktu widzenia), językiem [jakim] (np. mówiąc językiem trywialnym), w języku [czego] (np. ujmujac rzecz w języku statystyki). Wskazują one, ogólnie mówiąc, na sposób ujmowania pod względem treści i/lub formy tego, do czego odnosi się komentarz; stosunek niektórych ze wskazanych wyrażeń do przysłówka przypomina relacje zachodzace między tzw. przysłówkami względu a wyrażeniami eksplicytnie wskazującymi na brany pod uwage aspekt tego, o czym mowa, np. przygotowany kondycyjnie vs pod względem kondycyjnym, por. biorac rzecz naukowo vs $z$ naukowego punktu widzenia.

Wskazane tu ograniczenia be z pośrednio należy wiązać z przyjmowaniem przez przysłówek postpozycyjny względem Q-I akcentu frazowego, $z$ czym jest związane zachowywanie przez przysłówek $\mathrm{w}$ tym układzie (i tylko w tym) funkcji charakteryzowania czasownika czyn-

6 Por. także wyrażenie $z$ wierzchu biorac, _(Był to, $z$ wierzchu biorac, żartobliwy dwuosobowy show: zestaw przekomarzanek pewnej (norweskiej, a jakże) pary małżonków o niekrótkim stażu [NKJP]), które chociaż stanowi połączenie incydentalne, jest zrozumiałe, podczas gdy odpowiedni układ postpozycyjny, por. *biorac rzecz $z$ wierzchu, na akceptację, nawet „naciagana”, nie zasługuje, i to nie tylko ze względów formalnych, ale przede wszystkim semantycznych. 
nościowego. Jednak nie może tu oczywiście chodzić o główny przycisk zdaniowy, ten jest zarezerwowany dla elementu rematycznego i musi się znajdować poza metakomentującą częścią zdania; przycisk frazowy, o którym tu mowa, ma własną osobna motywację składniowa, por. Mówiac dos/adniej, ${ }^{7}$ jest IDIOTA. Jednak, choć to właśnie szyk postpozycyjny w naturalny sposób wydobywa element akcentowany, nie jest wykluczona identyczna realizacja prozodyczna w układzie przy odwróconym szyku elementów, tj. [Adv] Q-I, jest ona jednak wtórna i wymaga zastosowania specjalnych operacji na poziomie suprasegmentalnym (zwłaszcza pauzy przed Q-I oraz intonacji bardziej płaskiej niż w konstrukcji z prymarnie antepozycyjnym przysłówkiem), ${ }^{8}$ por.:

(17) Muzyka uruchamia $w$ naszym mózgu mechanizmy, w wyniku których, w uproszcz/eniu mówiąc, powstaja szczególnie pozytywne emocje.

(18) W pewnym przejaskrawi/eniu rzecz ujmujac: dla zwiazanej $z$ „noca”, lunarnej świadomości Rosji wszystko przenika się wzajemnie (...).

Dalej dla odróżnienia opisywanych tu dwóch typów metakomentarzy na oznaczenie pozycji przysłówka $z$ akcentem frazowym będzie stosowany zapis wersalikami - mówiąc [ADV], _ (przy dopuszczalnej wtórnej realizacji [ADV] mówiąc,_).

$Z$ tego względu dane statystyczne dotyczące liczby wystapień poszczególnych przysłówków w zależności od pozycji względem Q-I [zob. np. Kubicka 2017] nie dają wglądu w realne różnice, $z$ jakimi mamy tu do czynienia. I choć pokazuja preferencje czy nawet ograniczenia pewnych wyrażeń przysłówkowych co do zajmowanej przez nie pozycji, obserwacje te bez uwzględnienia wskazanych tu dystynkcji nie pozwalaja na formułowanie żadnych uogólnień na temat właściwości wyrażeń przysłówkowych w charakteryzowanych układach, por. przykładowe dane na podstawie korpusu zrównoważonego ${ }^{9}$ NKJP (przed ukośnikiem podaję wystapienia w antepozycji, po ukośniku - w postpozycji względem Q-I):

7 Za pomoca / oznaczam miejsce przycisku frazowego w układzie mówiąc $[A D V]$, ..

8 Analiza sposobu realizacji prozodycznej opisywanych tu układów wymagałaby uwzględnienia także ich pozycji w zdaniu, tzn. antepozycji, interpozycji i postpozycji względem tzw. zdania głównego oraz jego składników. Taki opis, bez zastosowania specjalistycznej aparatury, jest skazany na intuicyjne, ogólne impresje, bowiem semantyka lingwistyczna nie dysponuje odpowiednim aparatem metodologicznym, który byłby w stanie te zróżnicowania opisać. Użytkownicy języka rozpoznaja jednak odpowiednie dystynkcje na podstawie zachodzących między nimi opozycji [zob. de Saussure 2004].

9 Por. dla całego korpusu: np. delikatnie mówiąc (5491/766), ściśle mówiąc (355/88), najprościej rzecz ujmujac (120/6). 
Tabela 2. Rozkład statystyczny pozycji linearnej poszczególnych przysłówków względem Q-I

\begin{tabular}{|l|l|}
\hline mówiąc & $\begin{array}{l}\text { prościej (13/101), najprościej (97/105); ogólnie (178/71), } \\
\text { ogólniej (4/14), najogólniej (145/69); delikatnie (588/146), } \\
\text { delikatniej (1/1), najdelikatniej (38/26); dokładnie (37/23), } \\
\text { dokładniej (147/63), najdokładniej (0/1); generalnie (32/7); } \\
\text { ściśle (92/25), ściślej (318/69), najściślej (0/0); właściwie (125/0), } \\
\text { właściwiej (3/1); } \\
\text { por. np. * mówiąc gener/alnie, * gener/alnie mówiac itd. }\end{array}$ \\
\hline rzecz biorąc & $\begin{array}{l}\text { ściśle (53/1), ściślej (72/0), najściślej (0/0); ogólnie (431/0), } \\
\text { ogólniej (1/2), najogólniej (88/0) }\end{array}$ \\
\hline rzecz ujmujacc & $\begin{array}{l}\text { ściśle (10/0), ściślej (19/0), najściślej (0/0); prościej (1/1), } \\
\text { najprościej (29/2) }\end{array}$ \\
\hline
\end{tabular}

Źródło: opracowanie własne.

\subsection{Formy stopnia wyższego i najwyższego przysłówka w analizowanych konstrukcjach}

Wyróżnione konstrukcje cechuje także odmienny zestaw form stopnia przysłówków, z którymi się łączą, mianowicie zarówno [Adv] mówiąc, _, jak i mówiac $[A D V]$, _ dopuszczaja formy stopnia wyższego i najwyższego, por. ściślej, ogólniej, prościej, delikatniej, najprościej, ${ }^{10}$ ale jedynie w układzie mówiąc [ADV] mogą wystąić formy stopnia analitycznego, por.:

Tabela 3. Analityczne formy stopnia wyższego (comp.) i najwyższego (superlat.) w układzie typu mówiąc [ADV]

\begin{tabular}{|l|l|l|}
\hline \multicolumn{1}{|c|}{${\text { Q-I [ADV }]_{\text {comp. }}}$} & \multicolumn{1}{|c|}{ Q-I [ADV] $]_{\text {superlat. }}$} \\
\hline mówiacc & $\begin{array}{l}\text { mówiac bardziej melodramatycznie, } \\
\text { obrazowo, konkretnie, przyziemnie, } \\
\text { ogólnie, dosadnie, prozaicznie, } \\
\text { obrazowo, fachowo, precyzyjnie, } \\
\text { serio, wprost, szczegółowo, } \\
\text { naukowo }\end{array}$ & $\begin{array}{l}\text { mówiac najbardziej obrazowo, } \\
\text { oględie, ogólnie, lapidarnie }\end{array}$ \\
\cline { 2 - 3 } & $\begin{array}{l}\text { mówiąc mniej delikatnie, wytwornie, } \\
\text { patetycznie, metaforycznie, } \\
\text { obrazowo, elegancko, zręcznie, } \\
\text { szumnie, górnolotnie, oględnie, } \\
\text { kwieciście, uczenie; mówiąc mniej } \\
\text { górnolotnie, a bardziej uczenie }\end{array}$ & $\begin{array}{l}\text { mówiąc najmniej ogólnie, łagodnie, } \\
\text { naukowo }\end{array}$ \\
\hline
\end{tabular}

10 S. Birzer [2015, 90] uznaje pełna wariantywność (bez konsekwencji semantycznych) różnych form stopnia przysłówków w układach z Q-I. Nie ma tu miejsca na polemikę $z$ ta teza, stopniowanie w metatekście, choć podlega innym zasadom niż na poziomie przedmiotowym, wprowadza jednak w sposób regularny zmiany znaczeń form, które mu podlegają. 


\begin{tabular}{|l|l|l|}
\hline & \multicolumn{1}{|c|}{ Q-I [ADV $]_{\text {comp. }}$} & \multicolumn{1}{|c|}{ Q-I $[\mathbf{A D V}]_{\text {superlat. }}$} \\
\hline $\begin{array}{l}\text { rzecz } \\
\text { ujmując }\end{array}$ & $\begin{array}{l}\text { ujmujacc rzecz bardziej brutalnie, } \\
\text { ogólnie, precyzyjnie, jednoznacznie, } \\
\text { obrazowo, fachowo, życzliwie }\end{array}$ & $\begin{array}{l}\text { ujmujac rzecz najbardziej banalnie, } \\
\text { ogólnie, syntetycznie }\end{array}$ \\
\cline { 2 - 3 } & $\begin{array}{l}\text { ujmujac rzecz mniej abstrakcyjnie, } \\
\text { cynicznie }\end{array}$ & \\
\hline
\end{tabular}

Źródło: opracowanie własne.

W tym kontekście komentarza wymaga połączenie Q-I $z$ formami mniej, najmniej - ich użycie jest związane nie $z$ „obiektywnym” sposobem ujmowania danej treści ( ${ }^{*}$ mówiąc najg/orzej), ale jest wynikiem porównania przez mówiącego tego, co mówi, $z$ innymi możliwymi sposobami jej wyrażenia; w konsekwencji mniej/najmniej w danym mówieniu reprezentuje wybór pozytywny, np. mówiąc mniej ściśle (por. też Wypowiedź pana ministra Nowaka była, mówiąc delikatnie - niestosowna, a mówiąc mniej delikatnie - skandaliczna, ponieważ mówił, że się przymusi Narodowy Bank Polski). Stąd formie najmniej [jakoś] może towarzyszyć wyrażenie jak, np. jak najmniej uczenie itd. $Z$ kolei układ [Adv] mówiąc, służący do skomentowania jak najbardziej adekwatnego wyrażenia tego, co się mówi w danej wypowiedzi, pod groźbą sprzeczności nie akceptuje takiego „stopniowania w dół”, por. *mniej właściwie // *najmniej ściśle mówiac, _.

Wskazane właściwości potwierdzają, że w układzie mówiąc [ADV] mamy do czynienia $z$ użyciem jednostek przysłówkowych, wolnym od ograniczeń, jakie na element adwerbialny nałożone są w metakomentujacym [Adv] mówiąc. Różnica ta, a także zasygnalizowane wcześniej zróżnicowanie leksykalne przysłówków zależne od pozycji linearnej względem Q-I, jest zwiazzana $z$ czynnościowym charakterem elementu mówiąc w układzie mówiąc [ADV]. Tezę tę wspierają kolejne obserwacje dotyczace właściwości przysłówków w układzie mówiąc [ADV], mianowicie: są one semantycznie stopniowalne, por. (19), dopuszczaja zestawienia dwóch elementów przysłówkowych, por. (20), a także poddają się parafrazie za pomoca konstrukcji $w$ sposób [jakiś], por. (21); żadnej z tych właściwości nie spełniaja elementy inherentnie metatekstowe, por.:

(19) mówiąc bardzo // całkiem szczerze, poważnie, serio; mówiąc nieco eufemistycznie, trywialnie, żartobliwie, publicystycznie, dokładniej, nieco bardziej oględnie; mówiąc $w$ wielkim skrócie, $w$ największym uproszczeniu; mówiąc jeszcze inaczej, dokładniej;

(20) mówiac w skrócie i uproszczeniu; mówiac mniej patetycznie i bez epitetów; mówiąc mniej górnolotnie i bardziej precyzyjnie;

(21) mówiąc $w$ prosty sposób; mówiąc $w$ sposób uproszczony, obrazowy, drastyczny. 


\subsection{Negacja w quasi-imiesłowowych komentarzach metatekstowych}

Kolejną cechą różnicujaca charakteryzowane układy Q-I z przysłówkiem jest możliwość przyjmowania przez nie negacji. Istotą metatekstu jest komentowanie bieżącej wypowiedzi, ze względu na funkcję wyrażenia metatekstowe reprezentują więc użycia 1-osobowe i aktualne. Podstawowa zasada funkcjonowania negacji w metatekście polega na wykluczeniu jako wewnętrznie sprzecznych takich połaczeń metakomentujacych $z$ nie, które sprowadzaja się do orzekania niedokonywania działań (w szerokim sensie) zarazem dokonywanych, np. *nie podsumowujac, _; *nie mówię, że _; *nie mówiąc w największym skrócie,_. Wyrażenie nie w metatekście funkcjonuje zatem jako: a) segment wielowyrazowej jednostki języka, np. nie powiem, _ [zob. Danielewiczowa 2018], lub b) faktyczna negacja, która jednak jest odniesiona do czegoś innego niż samo wła śn ie realizow a n e działanie mowne, por. np. mówiąc niefachowo, _; mówiąc nie wprost, _; może nie najściślej rzecz ujmując, _; jeszcze nie podsumowujac, _. ${ }^{11}$

Inną motywacje maja anomalne semantycznie połaczenia metakomentarzy $z$ negacja, prowadzące wprost do sprzeczności, w postaci nieakceptowalnych układów wiedzy i działań. I tak, wykluczone jest, na mocy reguł najbardziej podstawowych, orzekanie fałszu tego, do czego odnosi się metakomentujące mówiąc, por.:

\section{(22) *Mylnie // błędnie mówiąc, mamy wzrost gospodarczy.}

W układzie [ADV] mówiąc przysłówek typu fałszywie, nieprawdziwie, mylnie, błędnie wskazywałby na jednoczesna świadomość mówiącego niezgodności z prawda tego, do czego się odnosi komentarz, i z a ra z e m mówienie na serio tego właśnie jako czegoś wiadomego (por. sprawozdawcze mylit się, mówiąc, że ...). Z kolei umieszczenie fałszywie czy mylnie w układzie mówiac [Adv] nadawałoby temu, co jest objęte takim komentarzem, ramę mówienia nieprawdziwego, co wykluczałoby cała wypowiedź z mówienia na poważnie, ${ }^{12}$ por.:

11 Ostatnio problem funkcjonowania nie w metatekście był przedmiotem analiz M. Stępień [2019].

12 Nie jest zaskakujące również to, że metakomentarze nie dopuszczają także kwalifikacji wprost prawdziwościowej, por. * Prawdziwie mówią, mamy wzrost gospodarczy; * Mówiąc prawdziwie, działania te doprowadziły $w$ prostej linii do wyraźnego ograniczenia regut czystej i twardej konkurencji. Motywowane jest to nie tylko tym, że za pomoca przysłówków typu prawdziwie czy słusznie kwalifikuje się działania mowne jedynie sprawozdawczo (ani nawet tym, że prawdziwie synkretycznie zawiera w sobie zarówno to, że ktoś tak powiedział, jak i to, że mówiący wie, że tak było, por. prawdziwie zmartwychwstał), choć właściwości te także trzeba by tu mieć na uwadze, ale tym, co pojawia się na pierwszym planie, jest właśnie niedopuszczanie oceny prawdziwościowej w układzie [Adv] mówiac, _ 
(23) *Mówiac fałszywie, działania te doprowadziły $w$ prostej linii do wyraźnego ograniczenia reguł czystej i twardej konkurencji.

Pojawiający się w układzie postpozycyjnym przysłówek przewrotnie nie jest objęty charakteryzowanymi tu zakazami, gdyż za jego pomoca charakteryzuje się działania, a nie ujmowane treści, por. przewrotnie nazwat to tak, przewrotnie interpretowano, powieść napisana przewrotnie. Przysłówek ten odniesiony do działań mownych służy do wskazywania na uświadamiany sobie rozdźwięk między stanami rzeczy a tym, co mówi nadawca, por.:

(24) Ale może Niemkom faktycznie zapadł w pamięć, bo dokładnie mnie pilnowały. Zreszta dzien wcześniej z Holandia było podobnie. I mówiac przewrotnie, bardzo się z tego cieszę. Dzięki temu na drugim skrzydle jest pusta siatka.

Rozpoznane właściwości konstrukcji z Q-I pozwalaja także na wyjaśnienie współwystępowania mówiąc $[A D V]$ z przysłówkami typu ironicznie, żartobliwie (a także poważnie, serio - zachodzi tu całkowita symetria), np.:

(25) Proszę mi wierzyć, że Polacy szybko się przekonali, iż - mówiąc żartobliwie - Pan Bóg po soborze nauczył się także języka polskiego.

(26) Sukcesy Wojskowych Służb Informacyjnych sa - mówiac ironicznie - najbardziej chroniona tajemnica WSI.

Za pomoca scharakteryzowanych właściwości układów typu [Adv] mówiąc i mówiąc [ADV] można wyjaśnić zarówno ograniczenia, jak i różnice zwiąane $z$ ich funkcjonowaniem $z$ negacją. Służący do ustanowienia ekwiwalencji danego działania mownego i wyrażanej treści układ [Adv] mówiąc nie przyjmuje negacji, por. * nie wprost mówiac, * nieogólnie mówiąc, *nieściśle mówiąc. $Z$ kolei układ mówiąc [ADV] dopuszcza wprawdzie negację przysłówka - co istotne, negatywna kwalifikacja do-

- komentarz tego typu, ze względu na swoją funkcję adekwatnego oddania tego, co się mówi, gwarantuje (w charakterze niejako warunku minimalnego) mówienie tego, co jest prawdziwe. Jest to komentarz czysto egocentryczny, angażujący wyłącznie własne charakterystyki wypowiedzi. Natomiast w układzie mówiąc $[A D V]$, _ pojawienie się przysłówka prawdziwościowego ma sens jedynie wtedy, gdy chce się zwrócić uwagę na to, że dana wypowiedź kontrastuje $z$ innymi, które prawdziwe nie były, por. np. Rewolucji nie zrobit, bo mówiąc szczerze, sportem przy Woronicza - a ponoć $i$ cała firma - rzadzi członek zarzadu, Piotr Gaweł. Na tym tle jasna staje się funkcja komentarzy szczerze mówiąc i prawdę mówiąc - nie dotykają one bezpośrednio oceny prawdziwościowej, ale sa świadectwem dążenia mówiącego do adekwatnego wyrażenia tego, co jest przedmiotem komentarza, por. Szczerze mówiąc, nie sądzę, żebyś zdradził Janka. 
tyczy wyłącznie charakteryzowanego sposobu danej czynności mownej, ale nie samej tej czynności, np. mówiąc niemetaforycznie, mówiąc niefachowo - jednak liczne ograniczenia związane $z$ pełniona funkcja metakomentarza (na różnych poziomach, por. np. naruszające Grice'owską maksymę sposobu *mówiąc nie zwięźle czy anomalne semantycznie ze względu na znaczenie przysłówka _, "nie mówiąc inaczej, _) powoduja, że wystapienie powierzchniowej negacji nawet i w tym układzie nie jest częste. Osobnego rozważenia wymaga także funkcjonowanie w opisywanych układach przysłówków w parach antonimicznych, np. mówiąc niedelikatnie vs brutalnie; mówiąc nie wprost vs *ogródkami; mówiąc żartem vs *niepoważnie; mówiąc ogólnie vs *nieściśle itd.; przykłady te potwierdzaja różnice semantyczne we wskazanych parach wyrażeń, które nie daja się sprowadzić do prostej relacji $p-n i e-p . Z$ dążnia mówiącego do jak najlepszego wyrażenia danej treści zdaja sprawę komentarze typu mówiąc nie całkiem / nie do końca [jakoś], np. nie do końca serio, nie całkiem wprost, a także połaczenia wskazujace na wahanie mówiącego co do trafnego ujęcia w rodzaju może nie najściślej mówiąc. Układ ten dopuszcza także kontrasty charakterystyk przysłówkowych typu nie historycznie, lecz poetycko mówiac. Na zasadach ogólnych także układ [Adv] Q-I może podlegać doraźnym działaniom językowym (nie w trybie serio), np.:

(27) Tak więc, ściśle rzecz biorac, nie masz racji. A biorac rzecz nieściśle, czyli zdroworozsadkowo, nie masz racji tym bardziej.

\section{FUNKCJA UKLADÓW [ADV] MÓWIĄC, _ I MÓWIĄC [ADV]}

Na podstawie wskazanych właściwości składniowo-semantycznych należy wyróżnić dwa osobne byty językowe związane $z$ Q-I, odpowiadające dwóm odmiennym typom komentarzy odnadawczych. Konstrukcja realizująca schemat mówiąc [ADV] jest wynikiem działania na czasowniku czynnościowym mówić i stanowi efekt (rezultant) operacji quasiimiesłowowej wskazanej przez Bogusławskiego i Danielewiczowa [2005, 347], skutkującej użyciem metatekstowym odpowiednich czasowników:

osobowa fraza czasownikowa ${ }_{\mathrm{i}}$ bez podmiotu oznaczająca wypowiedź lub działanie zmierzające do stworzenia wypowiedzi

imiesłów przysłówkowy współczesny ${ }_{\mathrm{i}}$

Natomiast układ [Adv] mówiąc jest metatekstowa jednostka języka. Dla oddania tej różnicy można by zastosować osobne terminy, mianowicie odpowiednio: komentarz mowny i komentarz metatekstowy. 
Komentarz mowny (por. mówiąc [ADV]) podlega w regularny sposób transformacjom składniowo-semantycznym, por. np. powiem (to) ściśle // inaczej // wprost: _; może współwystępować z metaoperatorem tak, np. tak mówiąc delikatnie, _; dopuszcza substytucję segmentu, por. ujmujac sprawe // problem inaczej, wprost itd.; a także rozsunięcie [Avd] i Q-I, np. wt/aściwie bowiem // jednak mówiac. Natomiast funkcja metatekstowego [Adv] mówiąc, _ polega na komentowaniu bezpośrednio tego, c o jest mówione. Ograniczenia leksykalne nałożone na łączliwość $z$ przysłówkiem wynikają $z$ tego, że za jego pomoca nie charakteryzuje się czynności mownych, por. mówię *gener/alnie, ale działania zmierzajace do ustanowienia ekwiwalencji między własnym stanem świadomości a treścią bieżącej wypowiedzi.

Przysłówki w komentarzu mownym pełnią funkcję modyfikatorów charakteryzujących realizowane właśnie czynności mowne, stanowią wynik użycia $\mathrm{w}$ metatekście jednostek poziomu przedmiotowego, ich zestaw jest ograniczony do tych przysłówków, które moga współwystępować $z$ aktualnym komentarzem odnadawczym. Także adwerbia występujące w układach [Adv] mówiąc- mimo że nie podlegają wskazanym wyżej transformacjom składniowo-semantycznym - muszą być interpretowane jako użycia przysłówków, nie ma bowiem podstaw do wyróżniania jakichś elementów „quasi-przysłówkowych”, ze wskazanej ich funkcji wynikają ograniczenia nakładane na łączliwość w tym układzie Q-I z danym przysłówkiem.

Co więcej, użycie tego samego przysłówka w układach [Adv] mówiąc i mówiac $[A D V]$ wymaga innej interpretacji jego funkcji w całej konstrukcji, por. np. krótko mówiac, _, w którym - w odróżnieniu od mówiąc kr/ótko, _- treść przysłówka nie dotyczy długości komunikatu, ale jego istotności (rzeczywista jego długość jest tu irrelewantna); por. przybliżone parafrazy: 'to, co powiem, najtrafniej oddaje, to, co chcę powiedzieć // mówię' vs ‘to, co powiem, jest krótkie'; analogicznie dla właściwie mówiąc vs mówiąc właśc/iwie czy inaczej mówiąc vs mówiąc in/aczej. Nie można się zatem zgodzić $z$ tezą Kubickiej [2017, 108], że mówiący za pomoca analizowanych tu układów z Q-I charakteryzuje skutek swojej wypowiedzi, ${ }^{13}$ przeciwnie, metakomentarze pojawiaja się $\mathrm{w}$ wypowiedzi na bieżąco i wspieraja jej jak najbardziej adekwatne wyrażenie. W świetle

13 Por. „nadawca, używając wyrażeń prymarnie metatekstowych, antycypuje niejako całość wypowiedzi i już w trakcie jej powstawania jest w stanie powiedzieć coś o jej kształcie, nazwijmy go umownie, językowym. Wyrażenia [jakoś] mówiąc można więc rozpatrywać jako „instrukcję” na temat sposobu odczytania komunikatu (ocena) lub informację o tym, że nadawca formułuje myśli nie tak, jak sa one reprezentowane w jego umyśle, ale zgodnie $z$ innym przyjętym przez niego systemem znaków lub odpowiednio do zamierzonych przez niego modyfikacji treści" [Kubicka 2017, 108]. Z teza ta koresponduje zaproponowana klasyfikacja przysłówków w układach $z$ Q-I, por. a) projektowanie oceny komunikatu (np. szczerze, otwarcie, oględnie, cynicznie, serio), b) operacje na komunikacie: 
zaproponowanej interpretacji zestawu i funkcji przysłówków w układzie [Adv] mówiac rewizji wymagaja hipotezy na temat statusu partykułowego połączeń w rodzaju krótko mówiąc.

\section{SAMODZIELNE UŻYCIA ELEMENTÓW PRZYSŁÓWKOWYCH W METATEKŚCIE}

Powyższe obserwacje rzucają światło na samodzielne użycia przysłówków w funkcji metakomentarzy w kontekstach typu (13)-(16). Jak zostało wskazane, w wyjaśnieniu tej właściwości wyrażeń nie można opierać się na hipotezach zrównujących dwa wyróżnione układy [Adv] z Q-I, por. np. przedstawiona przez E. Kubicka [2017] tezę o wpływie frekwencji i zajmowanej pozycji w zdaniu na emancypowanie się przysłówka. ${ }^{14}$

I tak, Q-I może być swobodnie pominięty w układach mówiac [ADV], np. (13); funkcja mówiac jest wtedy zastępowana przez wykładniki suprasegmentalne, por. niesłusznie zakwestionowany przez E. Kubicka [2017, 105] przykład Mówiage uczciwie, ani troche mnie ta gra nie ekscytuje i tak już pewnie zostanie do końca moich dni. W tej funkcji przysłówek dziedziczy wszystkie cechy właściwe konstrukcjom z Q-I, takie jak akcent, stopniowanie gramatyczne (w tym analityczne) i semantyczne itd. $Z$ właściwym „emancypowaniem się” przysłówka możemy mieć do czynienia wyłacznie $z$ wyzerowanym Q-I w układzie $[A d v]$ mówiąc, to w nim swoje źródło mają wyrażenia uznawane za samodzielne jednostki systemu, por. partykuły właściwie, praktycznie, generalnie, ogólnie [zob. SGPP]. „Zerowanie autoreferującej parentezy” [Kleszczowa 2015] może więc być doraźna właściwością użycia rozpatrywana w perspektywie synchronicznej (ściślej: realizacji) bądź procesem skutkujacym leksykalizacją odpowiednich przysłówków. Etapem pośrednim zmiany składniowo-semantycznej między przysłówkiem poziomu przedmiotowego a partykułą jest właśnie układ [Adv] mówiąc, por. ADV + V > ADV Q-I (V) > PART.

\section{Bibliografia}

S. Birzer, 2015, Generally speaking, connectivity and conversation management combined: the functions of Russian voobšče govorja and Polish ogólnie mówiąc, „Russian Linguistics” 39, 1, s. 81-115.

ba) wybór systemu znaków (np. inaczej, obrazowo, nieładnie), bb) modyfikacje treści (np. krótko, z grubsza, ogólnie, ściślej, prościej); [Kubicka 2017, 109].

14 Por. „Można więc zaryzykować tezę, że im częściej dany przysłówek występuje w kontekście mówiąc, tym bardziej się „emancypuje”, zajmujac antepozycję i przesuwając protetyczne mówiąc na pozycję nieakcentowaną" [Kubicka 2017, 104]. 
S. Birzer, 2017, Assessing the role of pattern and matter replication in the development of Polish discourse structuring elements based on non-finite 'verba dicendi, „Zeitschriftfür Slavische Philologie” 73 (1), s. 159-185.

A. Bogusławski, 1989, Uwagi o pracy nad frazeologia [w:] Z. Saloni (red.), Studia z polskiej leksykografii współczesnej III, Białystok, s. 13-31.

A. Bogusławski, 2008, Semantyka, pragmatyka. Leksykografa głos demarkacyjny, Warszawa.

A. Bogusławski, M. Danielewiczowa, 2005, Verba polona abscondita. Sonda słownikowa III, Warszawa.

M. Danielewiczowa, 2018, Co powiem, kiedy powiem „nie powiem”? Przyczynek do opisu idiomatyki metatekstowej, „LingVaria” 13(26), s. 61-80.

ISJP: M. Bańko (red.), 2000, Inny słownik języka polskiego, Warszawa.

A. Kisiel, M. Żabowska, 2011, O zakresie klasy partykuł $w$ „Słowniku gniazdowym partykuł polskich”, „Polonica” 31, s. 113-132.

K. Kleszczowa, 2015, U źródeł polskich partykuł. Derywacja funkcjonalna, przemiany, zaniki, Katowice.

E. Kubicka, 2017, Jak mówimy jakoś mówiąc? Formalne $i$ semantyczne właściwości adwerbialnych uzupełnień quasi-imiesłowowego mówiąc, „LingVaria” (1)23, s. 99-113.

A. Moroz, 2007, Uwagi o ciagach parentetycznych z segmentem mówiąc [w:] J. Kamper-Warejko, I. Kaproń-Charzyńska, J. Kulwicka-Kamińska (red.), Studia nad słownictwem dawnym i współczesnym języków słowiańskich, Toruń, s. 187-194.

A. Moroz, 2010, Parenteza ze składnikiem czasownikowym we współczesnym języku polskim, Toruń.

NKJP: Narodowy Korpus Języka Polskiego, on-line: www.nkjp.pl [dostęp: 22.02.2020].

F. de Saussure, 2004, Szkice z językoznawstwa ogólnego, tłum. M. Danielewiczowa, Warszawa.

SGPP: M. Grochowski, A. Kisiel, M. Żabowska, 2014, Słownik gniazdowy partykut polskich, Kraków.

M. Stępień, 2014, Wyrażenia parentetyczne $w$ strukturze wypowiedzi: właściwości semantyczne, składniowe, prozodyczne, Warszawa.

M. Stępień, 2019, Odimiesłowowe wyrażenia metatekstowe z segmentem nie w języku polskim - status językowy i funkcje, „Linguistica Copernicana” 16, s. $157-189$.

SWJP: B. Dunaj (red.), 1996, Słownik współczesnego języka polskiego, Kraków.

J. Wajszczuk, 1997, System znaczeń w obszarze spójników polskich. Wprowadzenie do opisu, Warszawa.

D. Weiss, 2005, Nowe przyimki o pochodzeniu imiesłowowym? [w:] M Grochowski (red.), Przysłówki i przyimki: studia ze składni $i$ semantyki języka polskiego, Toruń, s. 177-207.

H. Wróbel, 1975, Składnia imiesłowów czynnych we współczesnej polszczyźnie, Katowice.

WSJP: P. Żmigrodzki (red.), Wielki słownik języka polskiego, on-line: www.wsjp. pl [dostęp: 22.02.2020]. 


\section{Word order as a distinctive feature in the field of metatextual commentaries: [Adv] mówiąc, _[Adv] speaking, 」) vs mówiąc [Adv], _ (speaking [Adv], 」)}

\section{Summary}

The aim of this paper is to point to word order as a property differentiating linguistic entities in the class of metacommentaries. This property was not recognised in earlier analyses of quasi-participial structures with adverbs. As a result of the analyses, two arrangements have been distinguished, i.e. [Adv] mówiąc ([Adv] speaking) and mówiąc [Adv] (speaking [Adv]), which - along with linear and prosodic features - differ in terms of the following properties: a) syntactic and semantic, i.e. the set and form of adverbs, acceptable adverbial transformations, coexistence with negation; b) functional, i.e. the resultant of a quasi-participial operation vs. metatextual unit of the system, possibility to elide an adverb.

Keywords: adverb - quasi-participles - metatextual commentaries - word order

Trans. Monika Czarnecka 